\title{
'Bird-beak sign' of left atrial thrombus: a guide to management
}

\author{
Vivek Singla, Yadvinder Singh, Shankarappa K Ravindranath, \\ Cholenahally Nanjappa Manjunath
}

Department of Cardiology, Sri Jayadeva Institute of Cardiovascular Sciences and Research, Bangalore, Karnataka, India

\section{Correspondence to}

Dr Vivek Singla,

drviveksingla98@gmail.com

\section{DESCRIPTION}

A 24-year-old man presented with history of dyspnoea on exertion (New York Heart Association class III) of 4 months duration. After evaluation the patient was diagnosed as severe rheumatic mitral stenosis (MS) (mitral valve area $0.9 \mathrm{~cm}^{2}$ ) with dilated left atrium and atrial fibrillation (AF). The valve morphology was suitable for percutaneous trans-septal mitral commissurotomy (PTMC). Transesophageal echocardiography showed a large thrombus in left atrial appendage (type $\mathrm{Ib}$ ) protruding to the left atrium (LA). The thrombus had an echolucent centre giving appearance of bird's beak ('Bird-beak sign'; figure 1, see online supplementary video 1). The patient was started on aggressive anticoagulation, rate control and diuretic therapy. After 2 months the patient underwent successful PTMC.

LA thrombus is seen in up to $33 \%$ patients with mitral stenosis in $\mathrm{AF}$ and is associated with increased morbidity and mortality. ${ }^{1}$ The echolucent centre suggests that the thrombus is relatively new and is actively growing. ${ }^{2}$ This has practical

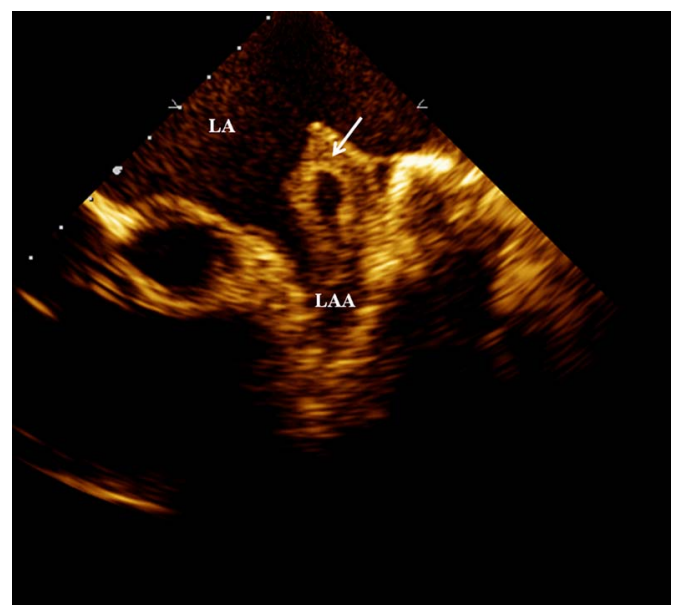

Figure 1 Transesophageal echocardiogram (colour B mode) showing thrombus (white arrow) with echolucent centre ('Bird-beak sign') in left atrial appendage slightly protruding to left atrium. importance for patient management as PTMC can be performed safely in presence of organised LA clot (types Ia, Ib and IIa). ${ }^{3}$ PTMC should be deferred till the clot resolves or get organised. Also the thrombus with echo-lucent centre caries a high risk of systemic embolism. ${ }^{2}$ The recognition of 'Bird-beak sign' in transesophageal echocardiogram carries paramount importance. These patients need aggressive anticoagulation and should be closely followed. The other risk factors for LA clot formation and embolisation in MS includes AF, LA size $>4.5 \mathrm{~cm}$, LA appendage emptying velocity $<20 \mathrm{~cm} / \mathrm{s}$, mobile thrombus and spontaneous echo contrast.

\section{Learning points}

Left atrial thrombus in mitral stenosis is associated with high morbidity and mortality.

- 'Bird-beak sign' in transesophageal echocardiography is marker of recent and growing thrombus.

- It is associated with high risk of thromboembolism. Thus aggressive anticoagulation should be given before percutaneous trans-septal mitral commissurotomy.

Competing interests None.

Patient consent Obtained.

Provenance and peer review Not commissioned; externally peer reviewed.

\section{REFERENCES}

1 Manjunath CN, Srinivasa KH, Panneerselvam AK, et al. Incidence and predictors of left atrial thrombus in patients with rheumatic mitral stenosis and sinus rhythm: a transesophageal echocardiographic study. Echocardiography 2011;28:457-60.

2 Armstrong WF, Ryan T. Feigenbaum's echocardiography. 7th edn. Philadelphia: Lippincott Williams \& Wilkins, 2010.

3 Manjunath $\mathrm{CN}$, Srinivasa $\mathrm{KH}$, Patil CB, et al. Balloon mitral valvuloplasty: our experience with a modified technique of crossing the mitral valve in difficult cases. Catheter Cardiovasc Diagn 1998;44:23-6. 
Copyright 2013 BMJ Publishing Group. All rights reserved. For permission to reuse any of this content visit http://group.bmj.com/group/rights-licensing/permissions.

BMJ Case Report Fellows may re-use this article for personal use and teaching without any further permission.

Become a Fellow of BMJ Case Reports today and you can:

- Submit as many cases as you like

- Enjoy fast sympathetic peer review and rapid publication of accepted articles

- Access all the published articles

- Re-use any of the published material for personal use and teaching without further permission

For information on Institutional Fellowships contact consortiasales@bmjgroup.com

Visit casereports.bmj.com for more articles like this and to become a Fellow 